総. 説

\title{
ハマチ養成網生筫における海水交流
}

\author{
井上裕雄 \\ (1971 年 11 月 5 日受理)
}

On Water Exchange in a Net Cage Stocked with the Fish, Hamachi

Hiroo INOUE*

1964 1966 年に水産庁指定調查事業として西日本諸県の水産試験場が主になつて 魚類養殖環境要因調査 を実施した。とくにハマチ養成に焦点を㧊き，多くの報告書が提出された。その調查においては数多くの養 魚場ないしは施設の環境条件がさまざまな視角から調査されており，水質，底質と同時に海水交流について

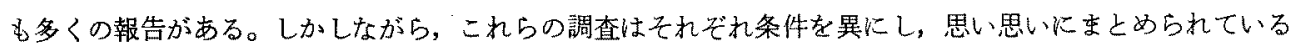
ために，そのまむでは十分活用しきれない恐れがあり，多くの解決されるべき問題を残している。

他方，八マ千養成事業のらちでも網生筫は年を追つて盛んになり，0才ものばかりではなく，2３才魚

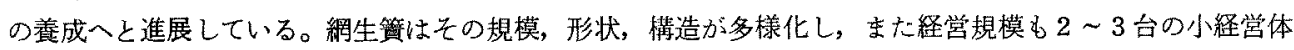
から数 10 台をかか文た大規模のものまでさまざをである。これらは主として内湾に設置されているため過 度に集中すると水質，底質の悪化をむたらす恐れがあり，琴実にそうした事例が生じている。盖魚場の老化 に対処するなめには，内海全体の地形，海水流動・交流の状況，水質，底質などを総合的に考虑して生筫の 適正な配置, 台数, 1 台当りの収容尾数などを決め, 合目的な保全管理を実施しなければならい。こういつ た合理的計画の基礎となる理論の確立が急がれるのであるが，本交ではその一つとして網生筫に淤りる海水 交流を取り上げ，各県水産試験場の魚類養殖環境要因調査報告書から本題に関係するものを選んで再整理し，

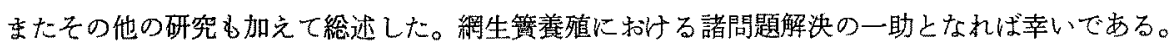

なお，取まとめに際し大島泰雄博士から多くの助言を賜わり，主た氷産庁本間昭郎企画官，東京大学平野 礼次郎助教授にお世話になつた。付記して謝意を表する。

\section{§1. 鋼生䈦における魚群活動と海水流動の状況}

一般に網生簤周辺の海水流動は, それが置かれている水域の潮流に生篢内に収容された魚群の運動によつ て生ずる流れが重嘼し，複雑な様相を呈する。

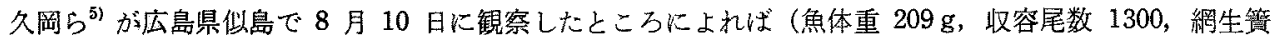
$5 \times 5 \times 4.5 \mathrm{~m}^{3}$, 目合 $3 \mathrm{~cm}$ ), 魚群活動の最も活発なのは投期時であり，夜明けの 4 時から 8 時までがこれに つぎ，かなり活発な旋回運動を行なつているといわれ，このとき網生簧内には $1 \sim 3 \mathrm{~cm} / \mathrm{sec}$ の旋回流を生

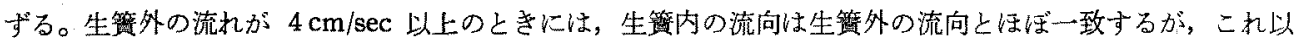
下になると收容魚の群行動の影響を受けて生簧内外の流向はかなりくい違い複雑になる。動きの緩慢なのは 22 時すぎから 4 時ごろまでの夜間であつて，ゆるやかな旋回をしているが，静止の状態にはならない。

德島水試 ${ }^{13)}$ が德島県中野で 8 月 26 ! 日儿行なつた潜水観察を含めた調査では(魚体重 $440 \mathrm{~g}$, 収容尾数 6000 , 網生䈌 $\left.4.5 \times 4.5 \times 3 \mathrm{~m}^{3}\right)$, 昼間平時には魚は水深 $1 \mathrm{~m}$ 層付近で静かに抒回群泳し, 海水は水面から $1 \mathrm{~m}$ く

* 香川大学農学部 (Fac. Agr., Kagawa Univ., Miki-cho, Kida-gun, Kagawa, Japan) 
らいの樑さまでの間で外から浸入し，生篢の中央部から斜め下方に流出している。投慨中には生䈯外で表面 で $10 \mathrm{~cm} / \mathrm{sec}, 1 \mathrm{~m}$ 層で $4 \mathrm{~cm} / \mathrm{sec}$ の速さで流出する。このとき海水は底層部から吸い上げられ，上層 0

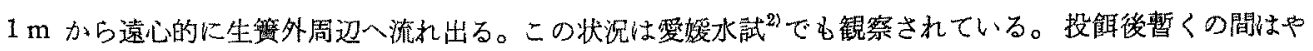
や弱くなるが，傾向としては投慨中と類似している。このような魚群の旋回運動の影響がかなり明確に認め られるのは生签設置水域の流速が $4 \sim 5 \mathrm{~cm} / \mathrm{sec}$ 以下のときであるという。このことは久岡ら ${ }^{57}$ の調査と一致 ナる。

岡山水試 ${ }^{11}$ 《設置水域の潮流がかなり速い場合について調べている(魚体重 $260 \mathrm{~g}$, 収容尾数 12400 , 檤

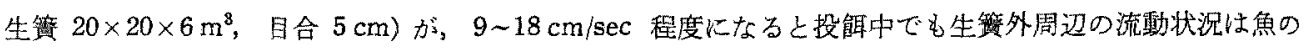
旋回群泳の影響起ほとんど受けないといら。

大分水試 ${ }^{12}$ の報告によれば，7，8月には早朝 5 時頃から水面下 $1 \sim 2 \mathrm{~m}$ 層を円渾動し，旋回流を伴う。

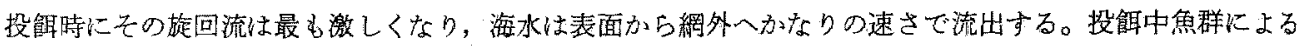
旋回流の中央木面下で着色水を詰めたゴム風船をるると円柱状に着色し，その後表面より周辺へ環状に払散 流出した。この実験は德島水試息が網なりの状況を潜水調查した前述の結諭を明確に立証している。魚群は 投慨後しばらくの間㶩下し，水面も平静であるが，再び群をなして円運動を始め，日中法行動が活発である。 夜間は多くは中層から下啳で不規則に散泳しており動作は緩慢である。ただし夜間投光器で長時間照明すれ

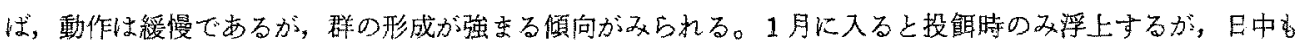
濚部にいる模様である。

\section{§2. 網生簧による流速の減衰}

ある水域に網生簧を設置した場合，絧生笻内の流れはその水域の流れとは買なる。網采の種類・撚り，䋧 の目合, 緇生賽の形状・大きさ, 付着物の種類・量, 設置方向, 網生筫相互の配置様式などによることはも ちろんのこと, さらに収容尾数, 魚の大きさ, 魚の活動状況, 水域の流れの状沉に上つて影響される。

茨城水試 ${ }^{6)} 1 \mathrm{~m}^{3}$ のモデル網生簙の前面を流九に直角におき，上流 $\left(U_{u}\right)$ と内部 $\left(U_{i}\right)$ および下流 $\left(U_{d}\right)$ の流速を測り， $U_{i} / U_{u} 、 U_{d} / U_{i}$ の值は網地総面積 $\left(S_{0}\right)$ に対する空間総面積 $(S)$ の比 $S / S_{0}$ 飞活に等しいと とを示した。たとえば $S / S_{0}=0.65$ のとき $U_{i} / U_{u}=0.65 \pm 0.04, U_{d} / U_{i}=0.64 \pm 0.03$ （ただし $U_{u}=$ $9 \sim 36 \mathrm{~cm} / \mathrm{sec}$ の範囲), また $S / S_{0}=0.86$ のとき $U_{i} / U_{u}=0.91 \pm 0.03, U_{d} / U_{i}=0.79 \pm 0.02$ (ただし $U_{u}$ $=22 \sim 38 \mathrm{~cm} / \mathrm{sec}$ の範囲)を得ている。したがつて，このような近似の簡単な関倸が成立すれば流九の方向 江配置された一連の緭生簧の第 $n$ 番目網生锤内の流速は

$$
U_{i n}=U_{u 1}\left(S / S_{0}\right)^{2 n-1}
$$

となる。S/S が知られていなくとも $U_{i} / U_{u}$ で置き代えてよい。

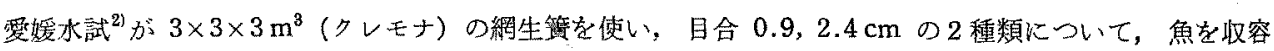

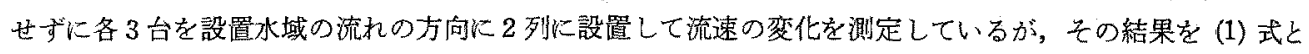
比較したのが Fig. 1 である。(1) 式である程度推算が可能であることがかかる。

$S / S_{0}$ は網への付着物の多寒に上つて变る。德島水試 ${ }^{13)}$ が行なつた網の浸漬テストによれば $6 ， 7$ 月炕最 も付着量が多く，次いで 10 月で，12月には最も少ない。また付着量は表篔が著しく多いという。

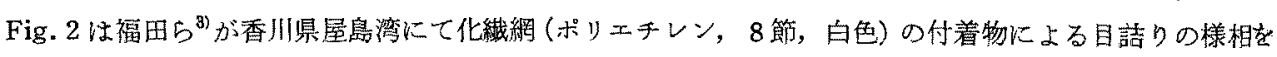
調べな結果の要約である。新しい網の通水面積に対する一定期間海中浸清後の通水面積の此が浸清期間によ つてどら変るかを示している。徳島水試の結果と同様に水面に近い網の部分に付着物が最も多く，20日前 後で通水面䅡が始めの $55 \%$ 程度まで減ずる。一般的には，(1) 設置後の 20 日間に多くの付着物があり著 しい目詰りを批こすがその後の20日間はあまり変化しない。しかしその後さらに20日の間に再び箸し い付着物が諗められること，(2) 水面近くで特に付着物に上る目詰りが影著であるといえよう。この上らに 網の污れ，つ可詰りは通水面積を著しく減じ，水の交流を阻害することになるのでとくに夏季には十分 配虑しなければならない。10〜15 日間隔で網替えを行ならことが理想といえる。 


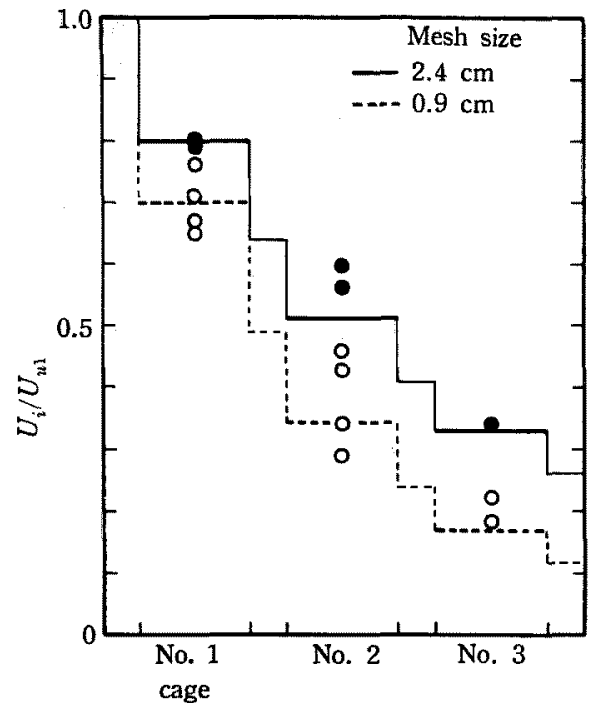

Fig. 1. Change of current speed in a series of floating net cages of different mesh size located parallel to the tidal current.

Size of net cage: $3 \times 3 \times 3 \mathrm{~m}^{3}$.

Current speed of the outside sea: 0.7 $1.9 \mathrm{~cm} / \mathrm{sec}$. No fish were stocked.

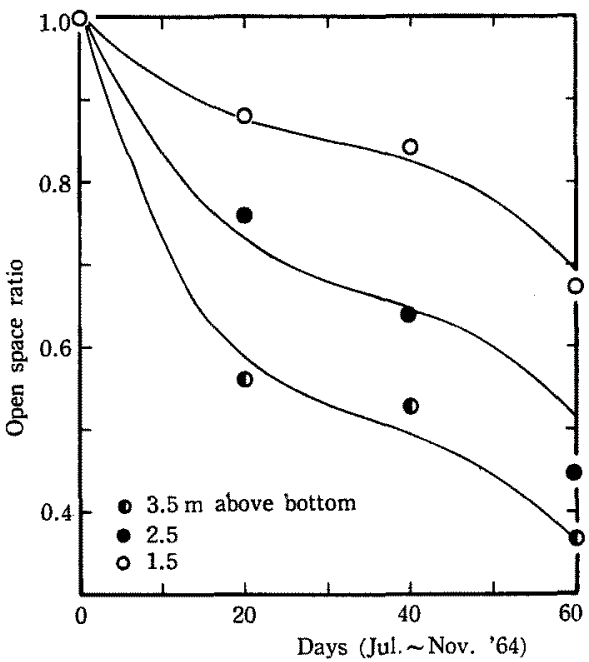

Fig. 2. Reduction of the open space area of a net soaked in the water of $\mathrm{Ya}$ shima Bay.

Mesh of the net: 24 yarns Polyethylen fiber, 8 knots. (By Fukuda et al.).

Table 1. Ratio of the mean current speed inside a net cage $\left(\bar{U}_{i}\right)$ to the speed of outside current in front of the cage $\left(U_{u}\right)$.

\begin{tabular}{|c|c|c|c|c|c|c|c|}
\hline $\bar{U}_{i} / U_{u}$ & $\begin{array}{c}\text { Size of } \\
\text { net cage } \\
\mathrm{m}^{3}\end{array}$ & $\begin{array}{c}\text { Mesh } \\
\text { size } \\
\mathrm{cm}\end{array}$ & $\begin{array}{l}\text { Current } \\
\text { speed } \\
\text { outside } \\
\text { net cage } \\
\mathrm{cm} / \mathrm{sec}\end{array}$ & $\begin{array}{c}\text { Body } \\
\text { weight } \\
\mathrm{g}\end{array}$ & $\begin{array}{l}\text { Number } \\
\text { of fish } \\
\text { stocked } \\
\times 10^{3}\end{array}$ & Method & Site \\
\hline 0.80 & $3 \times 3 \times 3$ & $2.4^{*}$ & $1.1 \sim 1.4$ & & 0 & A, B & Sakashizu, Ehime \\
\hline 0.69 & $3 \times 3 \times 3$ & $0.9^{*}$ & $1.1 \sim 1.4$ & & 0 & $A, B$ & $" \prime$ \\
\hline 0.50 & $6 \times 6 \times 6$ & $2.4^{*}$ & $4 \sim 10$ & 290 & 5.0 & $A, B$ & Akehama, Ehime \\
\hline 0.66 & $3 \times 3 \times 3$ & $2.4^{*}$ & $0.7 \sim 1.9$ & 310 & 0.27 & $A, B$ & Sakashizu, Ehime \\
\hline$(0.75)$ & $5 \times 5 \times 4.5$ & 0.5 & $5.3 \sim 5.8$ & 12 & 6.3 & $\mathrm{~B}$ & Ni-shima, Hiroshima \\
\hline 0.81 & $3 \times 3 \times 3$ & $2 *$ & $1 \sim 4$ & 100 & 0.3 & A & Ōita \\
\hline 0.35 & $20 \times 20 \times 6$ & $5 *$ & $9 \sim 18$ & 400 & 9.4 & A & Okayama \\
\hline$(0.67)$ & $20 \times 20 \times 6$ & $5 *$ & $9 \sim 18$ & 400 & 9.4 & B & Okayama \\
\hline 0.58 & $5 \times 5 \times 4.5$ & 0.5 & $4.9 \sim 15.1$ & 12 & 6.3 & $\mathrm{C}$ & Ni-shima, Hiroshima \\
\hline 0.73 & $5 \times 5 \times 4.5$ & 3 & $4.1 \sim 11.9$ & 210 & 1.3 & $\mathrm{C}$ & " \\
\hline$(0.77)$ & $10 \times 10 \times 6$ & $* *$ & $7 \sim 19$ & 300 & 6.0 & $B$ & Okayama \\
\hline
\end{tabular}

*: Curemona (Poly vinyl acetate).

**: Wire.

A: Dye method, B: Current meter method, C: Float method.

( ): Measurements of the current speed inside a cage were made near the wall of the cage. 
実際魚を収容した網生算の流速の減衰に関する従来の研究を Table 1 に括めだ。ただしこの場合, 投 餌時のデータは除いてある。網生筫外の流速 $U_{u}$ に対する網生笻内の平均流速 $\bar{U}_{i}$ の比は $0.35 \sim 0.81$ と

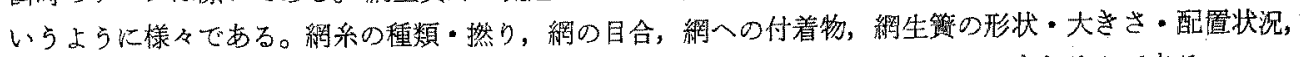
收容鲁の体重・尾数・活動状沉，設置水域の流動状沉・地形などに依存することはるちろんである。

§1で記述した上らに周辺水域の流速が大きければ，魚群の活動の影響は余りみられないが，4 5 cm/sec 以下の流速の場合には魚群の旋回運動の効果が著しく現われ，観測値のバラッキも大きく，特に投慨中には 外水域の 2 6 倍の流れを示すときさえあるという。

$\bar{U}_{i} / U_{u}$ (平均有效流速比々呼ぶことにする) としては $0.5 \sim 0.7$ を使用するのが普通の場合妥当であるら。 流れに平行に一連の網生筫（魚を收容）を設置した場合は一体どのようになるのであるらか，次のような

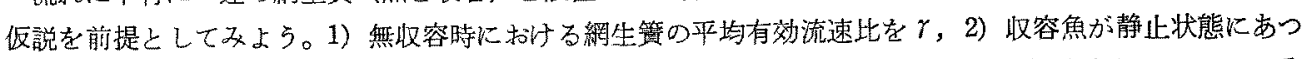
て，これにょる流速減の割合を $\lambda ， 3 ）$ 収容魚の活動（旋回群泳など）による平均付加流速をuとして，分 離し考えることができるとすれば，No. 1 の網生筫内の平均流速は

$$
U_{u} \gamma \lambda+u
$$

で示され，したがつて No. $n$ の網生筹内平均流速は

$$
U_{u \gamma^{2 n-1} \lambda^{n}}+u \frac{1-\left(\gamma^{2} \lambda\right)^{n}}{1-\left(\gamma^{2} \lambda\right)}
$$

となる。 $U_{u}$ は上流側での流速である。

Fig. 3,Fig. 4 は愛媛県水試が観測したデータと（2）式で計算した結果とを比較しだのである。Fig. 3

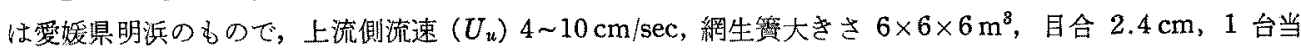

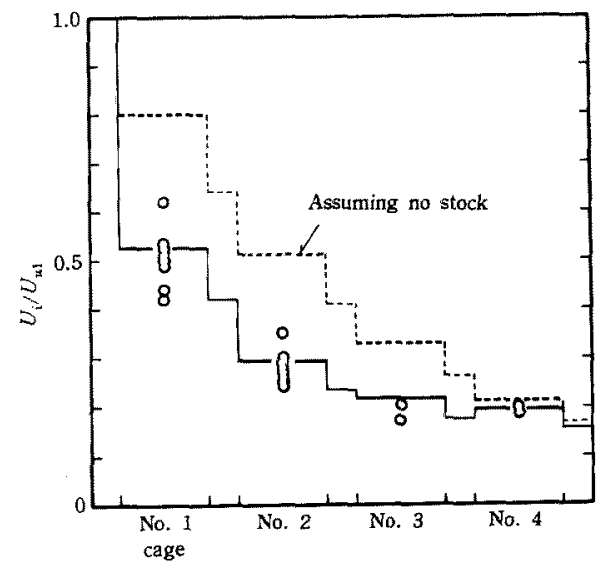

Fig. 3. Change of current speed in a series of floating net cages located parallel to the tidal current (Akehama, Ehime). Size of net cage: $6 \times 6 \times 6 \mathrm{~m}^{3}$.

Mesh size: $2.4 \mathrm{~cm}$.

Number of fish per one cage: 5000 .

Body weight: $290 \mathrm{~g}$.

Current speed of the outside sea: $4 \sim$ $10 \mathrm{~cm} / \mathrm{sec}$.

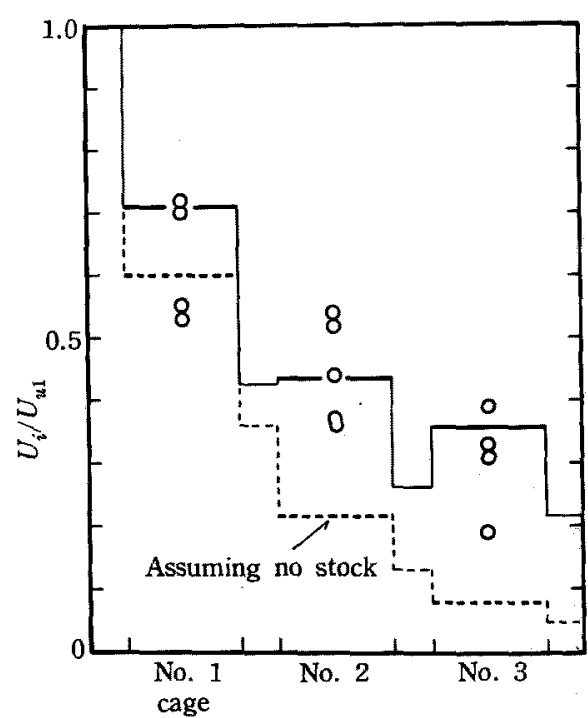

Fig. 4. Change of current speed in a series of floating net cages located parallel to the tidal current (Sakashizu,Ehime). Size of net cage: $3 \times 3 \times 3 \mathrm{~m}^{3}$.

Mesh size: $2.4 \mathrm{~cm}$.

Number of fish per one cage: 270 .

Body weight: $310 \mathrm{~g}$.

Current speed of the outside sea: $0.7 \sim$ $1.9 \mathrm{~cm} / \mathrm{sec}$. 
り収容尾数 $5.0 \times 10^{3}$ ，魚体重 $290 \mathrm{~g}$ である。 $r=0.8, \lambda=0.5, u=0.7$ として（2）式で計算した値（実 線）は観測值をよく説明している。図中の点線で表示したものは無収容時つまり $\lambda=1, u=0$ の場合であ る。1，2，3 番目までは無収容時上り生簊内平均流速は低いが，4番目では活とんど変らない。また収容時 に扎て 3 番目と 4 番目の間に洼とんぞ差のみとめられないことも特徽である。通過流速が次第に減ずるに つれて収容急の影響が大きく現われてきていることがわかる。

Fig. 4 は愛媛県坂下津の場合であるが, 上流側流速 $\left(U_{u}\right)$ は小さく $0.7 \sim 1.9 \mathrm{~cm} / \mathrm{sec}$ の䈥囲で，網生䇥 の大き $3 \times 3 \times 3 \mathrm{~m}^{3}$, 目合 $2.4 \mathrm{~cm}, 1$ 台当り収容尾数は 270 , 魚体重 $310 \mathrm{~g}$ である。 $\gamma=0.6, \lambda=0.8$, $u=0.3$ と見積つて（2）式から計算した平均流速（実線）は実测值上ほ注一致する。この場合，魚を収容 していない時 (点線) よりも網生䈠流速が魚群の活動で大きくなつている。特にこの現象は 2 番目， 3 番目 において顕著である(ただし投飭中は除外している)。

明浜では月 3 回の網替えがあり，坂下津では月 2 回の網替えであることを考慮してて值を見積つた。また 茨城水試がコイの網生筫湌殖で，網生筫の大きさ，目合いが同じであれば，コイの活動による水の交流量は 収容尾数に比例して增すことを示している。したがつて，明浜での収容密度は 23 尾 $/ \mathrm{m}^{3}$, 坂下津では 10 尾 $\mathrm{m}^{3}$ であつたことを考虑すれば，相対的にはこの両者に利子る付加流速は収容密度に比例するとしてよから ら。(ただし網生䈯の大きさの影響は無視している。） $300 \mathrm{~g}$ 程度の八マチを平面上に配置した場合， $1 \mathrm{~m}^{2}$ 当 りほ活 50 尾を並べることができるから，明浜で 23 尾 $/ \mathrm{m}^{3}$, 双下津で 10 尾 $/ \mathrm{m}^{3}$ の収容密度の場合, $1 \mathrm{~m}^{2} \mathrm{~K}$ 収容魚を重ならない上うに射影したときの空陵面積としてれを推算している。しかしながられ， は十分の裹付け資料に基づくものではなくこの上らな数值を仮定すれば一応観測結果の説明がつくといら 程度のことである。今後これらの諸点を明らかにしなければない。

\section{§3. 網生簧の海水交流}

網生筫の海水交流は設置水域の流机に上るものと収容魚の旋回群泳により蒸起される交流とからなる。こ のため極めて緩慢な流れの場に設置された網生䈯でもかなり高い収容密度を保つことができる。ただし多数 の網生䈯が相接して設置される場合は別である。

海水交流量を把握することは適正収容密度の決定へとつながる。

網生簧に批る海水交流量を測定する方法は，(1) 平均流速法，(2) 物質収支法，(3) 物質濃度希釈法汇 大別されよう。

\section{（1）平均流速法}

設置水域の流速が $4 \sim 5 \mathrm{~cm} / \mathrm{sec}$ 以上であつて，生筫内八マチの群泳の影響が著しくなく，生篢内外の流向 がほぼ一致するような条件の場合に適用できる。こ場合，色素を流すか，海流板を使用して生筫内の平均流 速を測定する。一定時間間隔で測定すれば時間交流率（1 時間以生䈯内を通過する水量をその生簤の容積で 割つた值) の日変化を知ることができる。網生筫内平均流速を $\bar{U}_{i} \mathrm{~m} / \mathrm{hr}$ ，これに直角な通水断面積を $A \mathrm{~m}^{2}$ とすれば，時間海水交流率は $\bar{U}_{i} \mathrm{~A} / \mathrm{V}$ である。 $\mathrm{V}$ は生筫の容積 $\mathrm{m}^{3}$ とする。

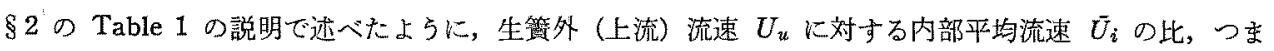
り平均有効流速比がかかつていれば，Uu を測定することにより，倍をを見積ることができる。ただし前記 のよらな諸条件により平均有効流速比はかなり変るので注意しなければならない。観测のできないときま たは設計に際しては，平均有効流速比として 0.5 0.7を使用するのがよい。

愛媛水試》は設管水域の潮流の日平均流速が $1.3 \mathrm{~cm} / \mathrm{sec}$ (1965 年 8 月 26 日大潮期) とかなり緩慢な坂 下津地区に設置された 6 台の粡生签 $\left(3 \times 3 \times 3 \mathrm{~m}^{\mathrm{R}}\right.$ ，目合 $2.4 \mathrm{~cm}$, 収容尾数 1 台当り $218 \sim 292$, 魚体重約 310 g）について，24 時間にわたり生筫内通過平均流速を測定し，日平均時間交流率を求め $4.9 \sim 7.3$ を得てい る。同年 8 月 20 日小潮期では $3.0 ~ 3.9$ の程度であつた。市た設置水域の潮流の日平均流速が $5.7 \mathrm{~cm} /$ $\sec \left(1965\right.$ 年 8 月 12 日大潮期) の明浜地先で 9 台の網生簤 $\left(6 \times 6 \times 6 \mathrm{~m}^{8}\right.$, 目合 $2.4 \mathrm{~cm}$, 収容尾数 1 台当り $4800 \sim 5200$, 魚体重約 $290 \mathrm{~g}$ ) Kついては, 日平均時間交流率 $7.9 \sim 15.3$ を得た。岡山水試 ${ }^{111}$ が目合 $5 \mathrm{~cm}$, 


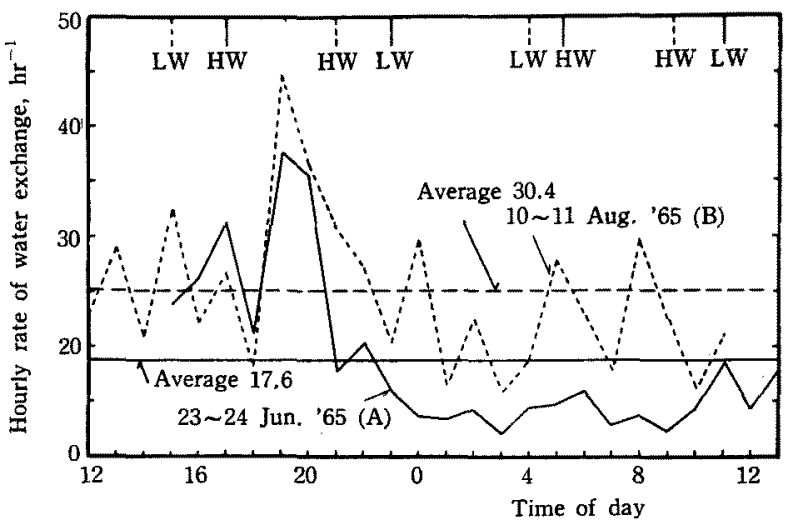

Fig. 5. Diurnal variation of hourly rate of water exchange in the net cage $\left(5 \times 5 \times 4.5 \mathrm{~m}^{3}\right)$ floated at the sea surface of Daiō Bay, Hiroshima.

Body weight: $A=12 \mathrm{~g}, \mathrm{~B}=209 \mathrm{~g}$.

Number of fish stocked: $A=6300, B=1300$.

Mesh size: $A=0.5 \mathrm{~cm}, B=3 \mathrm{~cm}$.

Current speed of the outside sea: $0 \sim 15 \mathrm{~cm} / \mathrm{sec}$.

Observations were made immediately after renewal of the net.
大き $20 \times 20 \times 6 \mathrm{~m}^{8}$ （魚体重 $260 \mathrm{~g}$, 収容尾数 12400) の絧生簣について 生筫内平均流速を色素, 海流板で測 定した。この結果から生簧外流速 $9.8(9 \sim 11) \mathrm{cm} / \mathrm{sec}$ 扰よび 16.0 (15 18) $\mathrm{cm} / \mathrm{sec}$ のときの時間海水 交流率としてそれぞれ 11.9 および 18.5 が得られる。

久岡 $5^{5)}$ は広島県大黄洿に設置さ た網生簧について海流板を使用し1 時間間隔で生簤内通過平均流速を測 定し, これょり時間海水交流量の日 変化を求めている。この結果を時間 海水交流率に换算し日変化として描 いたのが Fig. 5 である。生筫の大 き偣 $5 \times 5 \times 4.5 \mathrm{~m}^{8}$, 生筫外流速は $0.8 \sim 15 \mathrm{~cm} / \mathrm{sec}$ である。観測はい ずれも網替光直後に実施している。 6 月には網の目合が $0.5 \mathrm{~cm}$, 魚体 重 $12 \mathrm{~g}$, 収容尾数 6300 であり, 8 月に壮目合 $3 \mathrm{~cm}$, 魚体重 $209 \mathrm{~g}$, 収

容尾数 1300 であつた。一般的には夜間の交流率は小さく亘間は大きく，人マチの活動の様相と一致する。 つまりハマチの活動による海水交流の助長がみられる。8月の日平均時間交流率は 30.4，6月には 17.6 である。設置水域の潮流状況はほぼ同じであるのに 8 月の交流率の高いのは，魚体重の大きいこと，網の目 合が $3 \mathrm{~cm}$ と大きいことによるのであろう。19２0 時に時間交流率の高いのはいずれの日においても，こ の上げ潮ないしは下げ潮中期に設置水域の潮流が比較的速かつたことによるのであるが，他の上げ潮時には 速い流九を観測していない。理由はよくふからない。

\section{(2) 物诈収支法}

周辺水域の流速がかなり弱い場合でも，また平均流速法の適用できるかなりの流れのある場合にも適用で きる。通常は溶存酸素収支による。この方法を生簛に適用したのは橘高”)である。彼は光合成のない夜間の 生笻内の溶存酸素量は (3) 式に上つて変化するとした。

$$
\frac{d R}{d T}=\frac{Q_{i n}}{V}\left(R_{0}-R\right)+\frac{K_{L}}{H}\left(R_{S}-R\right)-\frac{C_{1}}{V}
$$

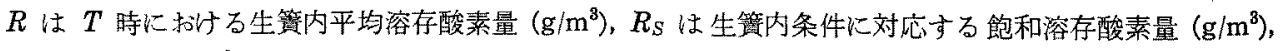
$V$ は生筫の容積 $\left(\mathrm{m}^{8}\right), Q_{i n}$ は単位時間に生簧に流入する水量 $\left(\mathrm{m}^{3} / \mathrm{hr}\right), K_{L}$ は物質移動俰数 $(\mathrm{m} / \mathrm{hr}), H$ は 生簧の深さ $(\mathrm{m}), C_{1}$ はハマチその他生篔内の生物・無生物に上る単位時間当り酸素消費量 $(\mathrm{g} / \mathrm{hr})$ である。

生镮内の溶存酸菜量はハマチの正常な生活に必要なある一定量を保つものとすれば， $d R / d T=0$ である から，(3) 式より

$$
\frac{Q_{i n}}{V}=\left\{\frac{C_{1}}{V}-\frac{K_{L}}{H}\left(R_{S}-R\right)\right\} /\left(R_{0}-R\right)
$$

樀高は時間海水交流率を（4）式から見積るために溶存酸素収支を適用したのではなく，周辺水域の流速 からハマチの収容量を推定したのである。

(4) 式において空気中からの酸素溶入の項を無視すれば 
Table 2. Oxygen contents inside and outside a net cage and hourly rate of water exchange.

\begin{tabular}{|c|c|c|c|c|c|c|c|c|c|c|}
\hline \multirow{2}{*}{$\begin{array}{l}\text { Site } \\
\text { and } \\
\text { date }\end{array}$} & \multirow{2}{*}{$\begin{array}{c}\text { Size of } \\
\text { net cage } \\
\mathrm{m}^{3}\end{array}$} & \multirow{2}{*}{$\begin{array}{l}\text { Mesh } \\
\text { size } \\
\mathrm{cm}\end{array}$} & \multirow{2}{*}{$\begin{array}{c}\text { Body } \\
\text { weight } \\
\mathrm{g}\end{array}$} & \multirow{2}{*}{$\begin{array}{c}\text { Number } \\
\text { of fish } \\
\text { stocked }\end{array}$} & \multicolumn{2}{|c|}{ Inside } & \multicolumn{2}{|c|}{ Outside } & \multirow{2}{*}{$\begin{array}{l}\text { Hourly } \\
\text { rate of } \\
\text { water } \\
\text { exchange }\end{array}$} & \multirow{2}{*}{ Note } \\
\hline & & & & & ${ }^{\circ} \mathrm{C} . \mathrm{T}$. & $\begin{array}{l}\text { D. O. } \\
\mathrm{m} l / l\end{array}$ & ${ }^{\circ} \mathrm{C} . \mathrm{T}$. & $\begin{array}{l}\mathrm{D} . \mathrm{O} \text {. } \\
\mathrm{ml} / l\end{array}$ & & \\
\hline \multirow{5}{*}{$\begin{array}{l}\text { Waka- } \\
\text { matsu } \\
6 \text { Aug. } \\
1965\end{array}$} & \multirow{5}{*}{$3.3 \times 3.3 \times 3.3$} & \multirow[t]{5}{*}{0.5} & \multirow[t]{5}{*}{$250 \sim 300$} & \multirow[t]{5}{*}{1500} & 25.2 & 4.33 & 25.0 & 4.70 & 10.9 & $\mathrm{~A}-2^{*}$ \\
\hline & & & & & 25.2 & 4.32 & 25.0 & 4.70 & 10.6 & $A-3$ \\
\hline & & & & & 25.0 & 4.47 & 25.0 & 4.70 & 17.6 & $A-4$ \\
\hline & & & & & 25.2 & 4.43 & 25.0 & 4.70 & 15.0 & $A-5$ \\
\hline & & & & & 25.4 & 4.36 & 25.0 & 4.70 & 11.9 & $A-6$ \\
\hline \multirow{2}{*}{$\begin{array}{c}\text { Ósaki } \\
17 \text { Aug. } \\
1965\end{array}$} & \multirow[t]{2}{*}{$10 \times 10 \times 4.5$} & \multirow[t]{2}{*}{3.8} & \multirow[t]{2}{*}{300} & \multirow[t]{2}{*}{3800} & 28.1 & 4.47 & 28.0 & 4.61 & 15 & $0900^{* * *}$ \\
\hline & & & & & 28.8 & 4.52 & 28.6 & 4.67 & 14 & 1200 \\
\hline
\end{tabular}

*: Mark of netting cages.

**: Time of day.

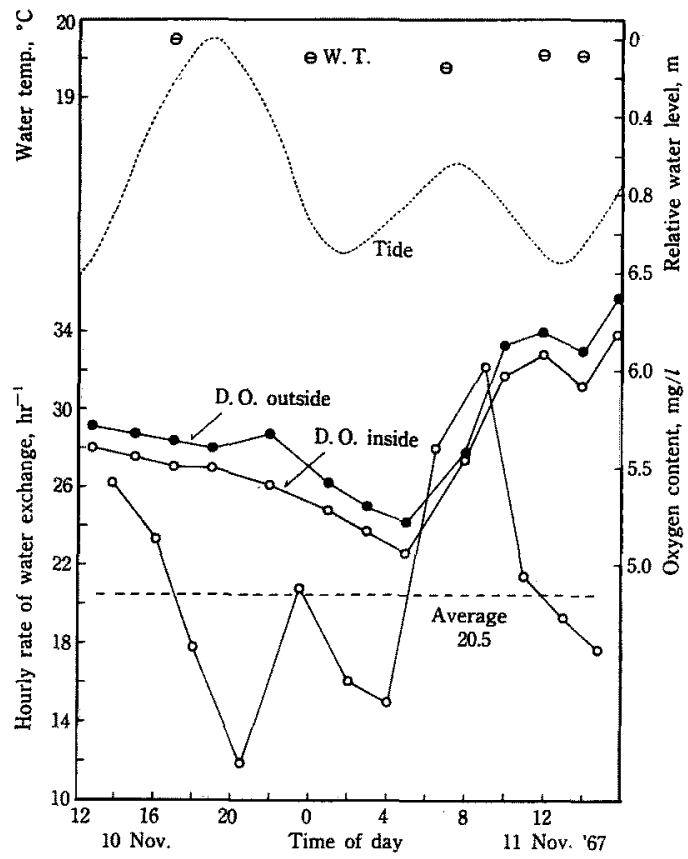

Fig. 6. Diurnal variations of water temperature, dissolved oxygen content, tidal level and hourly rate of water exchange in a net cage floated at the sea surface of Fukuda Fishfarm, Kagawa.

Size of net cage: $15 \times 15 \times 8 \mathrm{~m}^{3}$.

Mesh size: $6.1 \mathrm{~cm}$.

Body weight: $1 \mathrm{~kg}$.

Number of fish stocked: 10000.

$$
\frac{Q_{i n}}{V}=\frac{C_{1}}{V\left(R_{0}-R\right)}
$$

となる。江草" ${ }^{11}$ (5) 式の $C_{1}$ の鹤成要素の 主体は取容魚の呼吸であるとし， $C_{1}=k N(k$ は収容魚の単位魚体重当り箨位時間呼吸量 $\mathrm{g} / \mathrm{kg} \cdot \mathrm{hr} ， N$ は收容魚の総魚体重 $\mathrm{kg}$ ) とお いて，淡水とくに湖沼に設置した養甡網生篢 の時間交流率を求める方法を述べている。

この江草の方法にならつて，長崎水試 ${ }^{10)}$ は

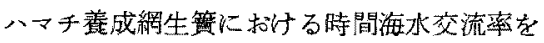
算出した。長崎県南松浦郡萑松（若松瀨戸の 小入江付近で潮通しがよい）と佐世保市大崎 (リアス式海岸に散在する島の近傍に設置さ れ潮通しがよい）での結果を Table 2 に示 す。若松では 8 月上旬, 網生簤の大きさ 3.3 $\times 3.3 \times 3.3 \mathrm{~m}^{3}$, 目合 $0.5 \mathrm{~cm}$, 魚体重 $250 \sim$ $300 \mathrm{~g}$, 収容尾数 1500 の場合, 時間海水交流 率は 10.6 17.6 であり, 大踦では 8 月中旬 網生簣の大さ巳 $10 \times 10 \times 4.5 \mathrm{~m}^{3}$, 目合 3.8 $\mathrm{cm}$, 魚体重 $300 \mathrm{~g}$, 取容尾数 3800 の場合に, 時間海水交流率は 14 15 であつた。

井上ら ${ }^{7}$ は網生簤内溶存酸素量は (6) 式に よつて表わされるとした。

$$
\begin{aligned}
\frac{d R}{d T}= & \frac{Q_{i n}}{V}\left(R_{0}-R\right)+\frac{K_{L}}{H}\left(R_{S}-R\right) \\
& -\frac{k N}{V}+\left(P_{P}-P_{C}\right)
\end{aligned}
$$

$P_{P}, P_{C}$ はそれぞれ生算内単位容積海水の単 

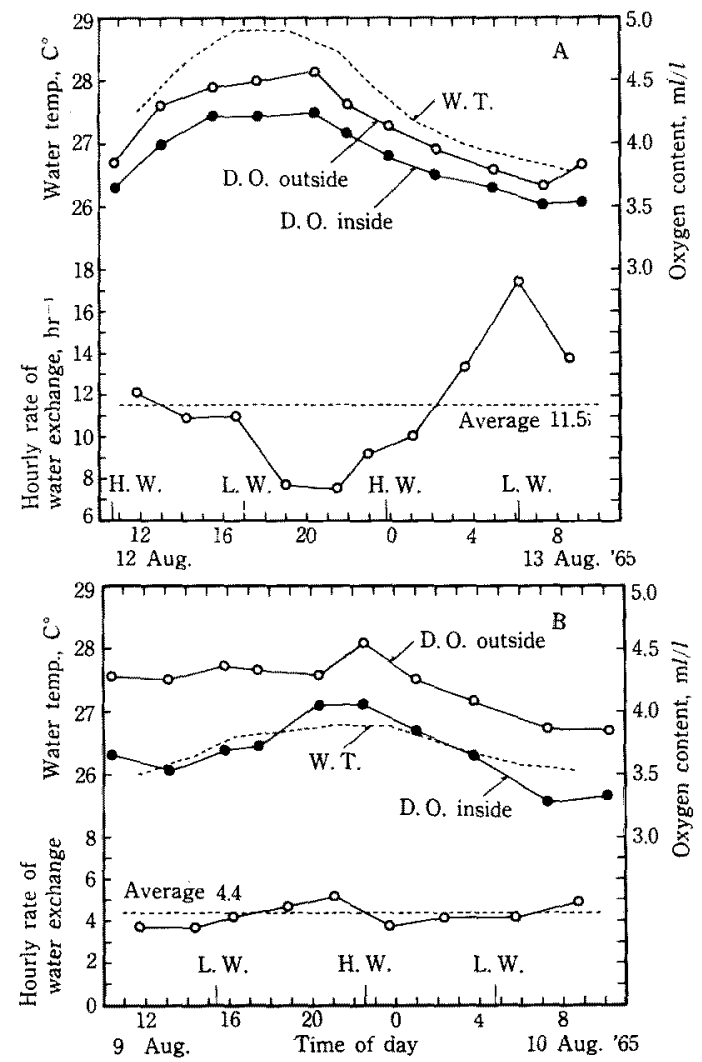

Fig. 7. Diurnal variations of water temperature, dissolved oxygen content and hourly rate of water exchange in the cage of doublewalled netting floated at the surface of Shido Bay, Kagawa.

Size of net cage: inside $7 \times 7 \times 3 \mathrm{~m}^{3}$, outside $9 \times 9 \times 3 \mathrm{~m}^{3}$.

Mesh size: inside $3.4 \mathrm{~cm}$, outside $3.0 \mathrm{~cm}$.

A: 1 day after renewal of the net. Body weight of the fish $250 \mathrm{~g}$, Number of fish stocked 3000 .

B: 13 days after renewal of the net. Body weight of the fish $225 \mathrm{~g}$. Number of fish stocked 3000 .
位時間当り酸素生産量（光合成に上る）と酸 素消費量である $\left(\mathrm{g} / \mathrm{m}^{3} \cdot \mathrm{hr}\right)$ 。実際には $d R / d T$ は0でなく、また一定でむない。生筫内平均 溶存酸素量は様々な日変化を示す。(6) 式か b

$$
\begin{aligned}
\frac{Q_{i n}}{V}= & \left\{\frac{d R}{d T}-\frac{K_{L}}{H}\left(R_{S}-R\right)+\frac{k N}{V}\right. \\
& \left.-\left(P_{P}-P_{C}\right)\right\} /\left(R_{0}-R\right)
\end{aligned}
$$

井上ら”は（7）式によつて時間海水交流率 の日变化の模様を調べた。香川県小豆島福田 にて，2 時間間隔で生簤内 2 点 $(1,2,5 \mathrm{~m}$ 深), 生簤外 2 点 $(1,2,5 \mathrm{~m}$ 樑) の溶存酸 秦量を測定し，同時に生筐周辺で明・暗瓶法 にて $P_{P}, P_{C}(0.5,1,2,5 \mathrm{~m}$ 深) を測つた。 1967 年 11 月 10 11 日である。網生簧の 大きさは $15 \times 15 \times 6 \mathrm{~m}^{3}$, 目合 $6.1 \mathrm{~cm}$, 魚体重 $1 \mathrm{~kg}$, 収容尾数 10000 尾で, $k$ の值として 夜間 $0.40 \mathrm{~g} / \mathrm{kg} \cdot \mathrm{hr}$, 昼間 $0.55 \mathrm{~g} / \mathrm{kg} \cdot \mathrm{hr}$ を使 用した。 $K_{L}$ は流机の状沉から判断し 0.06 $\mathrm{m} / \mathrm{hr}$ とした。海水の $\mathrm{O}_{2}$ 棇生産量は平均(網 生簧深の間) $0.604 \mathrm{~g} / \mathrm{m}^{3} \cdot$ day， $\mathrm{O}_{2}$ 消費量は $0.582 \mathrm{~g} / \mathrm{m}^{3}$.day であつた。 $0_{2}$ 総生産量は 1 $\mathrm{m}$ 深での水中照度により配分 L, 各時間間 隔での平均 $P_{P}$ とした。このよらにして求 めた時間海水交流率の日变化は Fig. 6 のと おりである。

自明のことながら，一般的には，上げ潮・ 下湆潮時に時間交流率は大きく，幾分時問の 遈机惊あるが潮の停滞する頃に交流率は小さ い。夜間に和子る時間交流率は 11.9 20.8 (平均 16.5), 昼間には $17.7 \sim 32.2$ (平均 24.0)で，日平均としては 20.5 を与えること ができる。日出の約 1 時間前頃からハマチの 運動が活発になり、これにより惹起される海 水交流が潮流による交流比付加されて 10 11 時頃まで交流率は大きい。その後、マチ

の活動は平常に復するが，夜間に比べればはるかに活動的であることがわかる。

井上ら ${ }^{7)}$ は香川水試 8 が香川県志度湾奥部仁設置した網生筫について 2 時間間隔で内 $(0,1,2,3 \mathrm{~m}$ 深)， 外 $(0,1 ， 2 ， 3,4 \mathrm{~m}$ 深) で溶存酸素量を測定した結果を(7) 式を適用して解析し Fig. 7-A と 7-B を 得ている。この場合， $k$ の值として昼間 $0.88 \mathrm{~g} / \mathrm{kg} \cdot \mathrm{hr}$ ，夜間 $0.60 \mathrm{~g} / \mathrm{kg} \cdot \mathrm{hr}$ を用い， $P_{C}$ として $0.06 \mathrm{~g} / \mathrm{m}^{3}$.

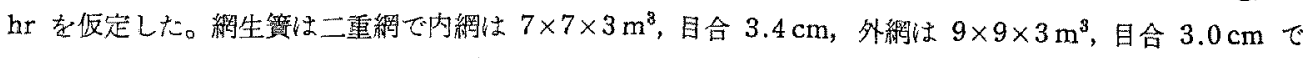
ある。8月 9 10日 (Fig. 7-B) 比焦体重 $0.225 \mathrm{~kg}$, 収容尾数 3000 で網替党後 13 日を経ている。あま 


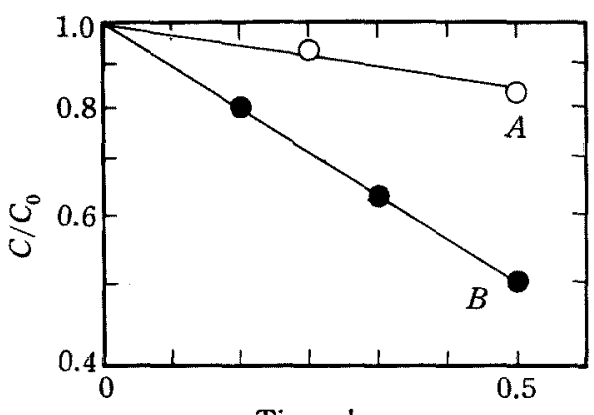

Time, hr

Fig. 8. Change with time of the concentration of Fluorescence Dye in two kinds of cages.

A: $0.9 \times 0.55 \times 0.4 \mathrm{~m}^{3}, 30$ mesh, in a small pond.

B: $5 \times 5 \times 5 \mathrm{~m}^{3}$, in Kasumi-ga-ura.

り明瞭に潮汐による変化やハマチの活動による変動 がみられないのは，湾奥部に設置されていて流れが 㥛度に緩慢であること，および二重網でしかも目詰 りがひどかったことによるものであるう。生簤内外 の溶存酸素量の差が大きい。平均時間交流率汇 4.4 である。

8 月 $12 \sim 13$ 日 (Fig. 7-A) に忙畺体重 $0.25 \mathrm{~kg}$, 収容尾数 3000 で前回の調查日と大差ないが, 網替 之直後であつた。前回同様潮汐に上る時間交流率の 变化は明らかでないが，ハマチの活動の影響はかな り明膫である。夜間の時間交流率は小さく $(7 \sim 10)$ ， 日出前の 4 時頃がらハマキの活動が激しくなり 10 時頃までの交流率はきわめて大きい（11～18)。日 平均は 11.5 であつた。8月 9 10日比べて焦 の活動の影響がはつきり現われ，交流率も大きいの は網替兄後 1 日目であつたことによる。このように 網の目詰りは海水の交流を著しく阻害するから，特位置水域の流れがきわめて緩慢な場所ではこの点注意 が必琶である。

なお，溶存酸素収支法によつて海水交流率を算出する場合，飼育魚の呼吸量の見積りが結果に大きく影響

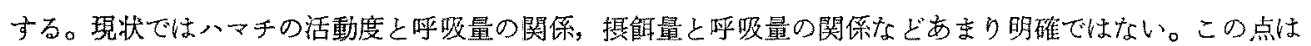
今後の研究課題として残る。

\section{（3）物啠漕度希勫法}

内潜の奥部の上らにきれめて流饥の緩慢な水域に網生筫を設置したような場合には, 魚群の旋回運動が海 水交流の主役を演ずることになる。したがつてこの場合網生簤内通過平均流速は測定できず，また網生筑内 外の酸素量の日変化から前述の方法によつて時間交流量を求め上らとすれば網生簤外の測点の選定が問題に なる。なぜならば，網生筫の影響が全周辺比打よび溶存酸素量の水平・垂直分布の状態を十分把握しなけれ ばならず，ぬた把握したとしても依然として流入水の溶存酸素量の決定が困難である。

この上らな場合には, 茨城水試がが行なつた fluorescene 濃度希勫法が海水交流率を見積る1つの方法で あろう。fluorescene を投入しょく翼汼し $T=0$ での濃度 $C_{0}, T=T$ に和ける濃度 $C$ とすれば

$$
C=C_{0} e^{\left(-Q_{i n} / V\right) T}
$$

の関保があるから，初期漉度と $T$ 時間後の濃度を測定すれば $Q_{i n} / V$ を推算できる。

荻城水試は池拉上び霞ヶ浦北浦で魚を収容しない場合について前記方法できわめて流れの緩慢な状態ての

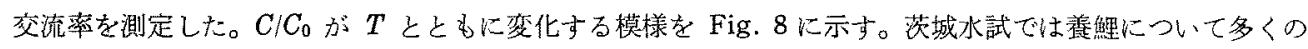
データを出しているが，それによれば，交流量は収容尾数に比例して增加すること，コイの体重の增加とと むに交流量が急增することを明らかにし，極めて緩慢な流れの水域では収容コイが水の交流を促谁する役制 が大きいと述べている。今後これに類似の方法によつて、マチ養成網生筑についての研究が期待される。

\section{文献}

1) 江草周三：第 4 回人工湖籼用部会餈料，全国湖沼河归菱殖研究会 (1963).

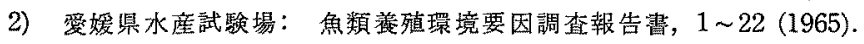

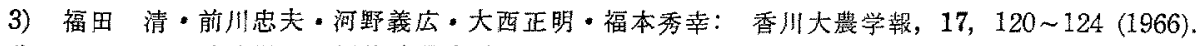

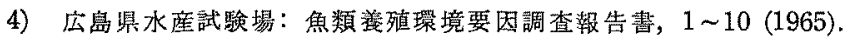

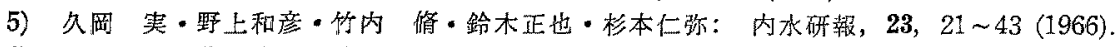

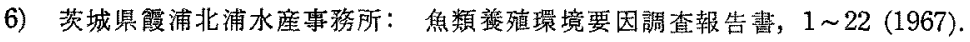


7) 井上裕雄・国中啓陽：末発洨（本誌投稿予定）。

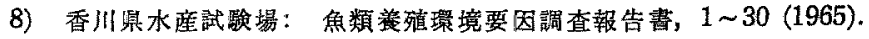

9）增高二郎：水産增殖， 7, 7 30 (1959).

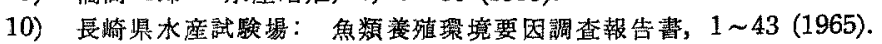

11)汹山県水産試験場：同誌，1２3(1965).

12) 大分罧水座試驗場：同誌，1 26 (1966).

13) 德島県水産試虽場：同誌，1３2 (1965). 